\title{
Proposal of analytical records for choreographic compositions in gymnastics for all
}

CDD. 20.ed. 796.41

http://dx.doi.org/10.1590/1807-55092016000100159
Maria Letícia Abud SCARABELIM*

Eliana de TOLEDO*
*Faculdade de Ciências Aplicadas, Universidade Estadual de Campinas, Campinas, SP, Brasil.

\begin{abstract}
Gymnastics for All (GfA) is a practice found in the wide world of gymnastics and its greatest form of expression is through choreographic compositions (CC) due to historical and pedagogical reasons, among other factors. In addition, in the international arena, gymnastics festivals have become a privileged forum to perform CC as they take place in different contexts of social intervention, such as schools, clubs, associations, NGOs, and universities. In this context, our objective is to provide a tool to register and analyze GfA choreographic compositions by means of analytical record system. Based on bibliographical and documentary research, we propose a set of eight aspects that address general and specific aspects of CC in GfA. We conclude that the proposed tool displays a didactic and very detailed structure that is based on the theoretical prerogatives of the area. Not only it is useful to professionals and practitioners with different profiles, but it also holds the power of being of great value to all those involved in the processes of CC in GfA as a tool for recording data (including historical data), which is a catalyst for processes of reflection and changes (whenever they are required).
\end{abstract}

KeY WoRds: Gymnastics for all; Choreographic compositions; Science of sport; Routine.

\section{Introduction}

Gymnastics for All (GfA), formerly called General Gymnastics (GG), is a practice that belongs to the broad universe of Gymnastics ${ }^{1}$ and that has currently become a unique practice, given some of its peculiarities.

GfA may be defined as "the foundation for all gymnastic disciplines, physical movement and sporting activities"2. Therefore, it may involve all kinds of gymnastics (Artistic, Rhythmic, Acrobatic, etc.), as well as other expressions of body language and practices, as pointed out by Perez-Gallardo and Souza ${ }^{3}$ :

An expression of body language that combines various interpretations of gymnastics (Natural, Standardized, Artistic, Rhythmic, Aerobics, etc) and blends them with other practices (Dance, Folklore, Games, Theatre, Mimicry, etc.), in a free and creative way, according to the characteristics of the social group, promoting social interaction among participants (p.292).

Besides, GfA

offers a variety of activities suitable for all genders, age groups, abilities, and cultural backgrounds.
Gymnastics For All activities contribute to personal health, fitness and well being - physical, social, intellectual and psychological. ${ }^{2}$

Based on these references, we can see it as an expression of the body language and the universe of gymnastics that focuses on leisure, both inclusive and participatory in nature, and that is typically expressed through a presentation of a choreographic composition (CC).

Choreographic compositions are part of a vast universe of Arts, which encompasses Performing Arts, Circus Arts and Dance. Some gymnastic practices have artistic features ${ }^{4}$, whether they are sports-based (especially Rhythmic and Artistic Gymnastics) or performance-focsed (such as GfA). In all these practices, CCs can be conceived with various aspects, including technical elements (formations, poses, transitions, etc) and aesthetic elements. Dantas ${ }^{5}$ is one of the authors who advocate this premise by point out that "movements and gestures [...] allow impressions and conceptions to be made; experiences 
to be represented; values, sense and meaning to be projected, and feelings, sensations and emotions to be revealed [...]". Therefore, while analyzing choreographies, all these aspects should be taken into account through the analysis of four operations: description of events in its structure, assessment of how it works, interpretation of its intentions and contextualization of its message, whatever it is ${ }^{6}$.

Rudolf $\mathrm{LABAN}^{7}$, the greatest theorist of Dance in the 20th century, proposes that CCs should display a combination of these elements, which he calls "outer forms of movement" e "elements of emotional content", as addressed in his theory:

Choreology is the logic or science of Dance, which could be understood as a purely geometrical study, but in fact is much more than that. Choreology is a kind of grammar and syntax of the language of movement, dealing not only with the outer forms of movement, but also with its mental and emotional content. This is based on the belief that movement and emotion, form and content, body and mind are an inseparable unit (p.viiii).

Assuming that CCs are made of elements that have in themselves different forms of expression, meaning and objectives, CRIOLlo ${ }^{8}$ stresses out that they can be interconnected, based on a thematic motif,

[...] which is the idea related to the content of dance, the cornerstone on which an "ARMAZON" of movements is developed. It can be a narrative or an image, when the motif comes from a literary narrative or story, from the spirit of a musical piece, from a character, from an emotional state, etc.

Choreographic compositions in GfA can be understood as ${ }^{9}$, compositions of a particular routine that mainly rely on body elements, predominantly associated with gymnastics, in a logical and harmonious interconnection that has a beginning, middle and end, with or without apparatus, be they large and/or small (p.43).

According to Gerlin ${ }^{10}$, from her studies and experiences in the European Gymnastics Union (UEG), "choreography means for our group in General Gymnastics the process and the products of creation". In her view, the following are the elements required to create a choreography: space, time, music, movement, objects, and actions; considering that movements are interconnected with all the other elements at all times.

Such choreographic compositions may include, in addition to the gymnastic elements, other practices and body languages (dances, circus activities, performing arts, games, sports, etc.), thus allowing endless inter-combinations ${ }^{11-13}$ resulting in creative, innovative and unique CCs, which seem to be crucial for the group's harmony and cohesion, as well as for enhancing the perception of rhythm. For Pollatou et al..$^{14}$, the CC

plays a very important role in physical education and dance activities because any complex athletic or artistic movement has its own duration and continuity, which must be perceived by the performer (p.98).

Some authors in the area claim that CC is part of GfA, while others attribute its importance to its educational and motivational character for the group ${ }^{15}$. SILvA ${ }^{16}$ proposes that $\mathrm{CC}$ can also be regarded as the "synthesis of the learning process of GfA", and in its development process, many foundations can emerge and be encouraged: creativity, participation, human development, relationship with elements of the body expressions, etc ${ }^{13}$.

In this regard, Ayous ${ }^{12}$ stressed that: When we consider general gymnastics as something to be performed, we must ensure that it will not be seen only as a "product" disconnected from a process. On the contrary, this perspective of performance in general gymnastics (GG) needs to be treated as an integral part of the educational process of GG [...] in the process of creating a choreographic composition, the students' experiences and interests as well as the tenets of team spirit must take precedence, by encouraging cooperation, the ability to take actions and the students' autonomy as subjects of the educational process, where co-authoring with other subjects may take place while seeking new interpretations, new readings and new meanings that were previously unknown.

For these reasons, we consider that choreographic compositions in GfA are of utmost importance, and have been treated as such, not only by a considerable number of researchers, but also by its practitioners and managers. This can be seen, for example, in the relevance of the gymnastics festivals around the world, from local events (in schools, clubs, associations, universities etc.) to the most traditional and pompous gatherings, such as Slet (Sokol) $)^{17-18}$, Deutsch Turnenfest ${ }^{19}$, World Gymnaestrada ${ }^{12,20-21}$ and others.

Patrício and Bortoleto ${ }^{22}$ point that [...] the educational and training values of Gymnastics Festivals can also be considered of great importance for the development of gymnasts, professionals, spectators, organizers and institutions. Generally speaking, these events 
contribute to the maintenance of the gymnastics tradition, reaching a wide range of countries, with secular traditions in the realm of gymnastics or not, as is the case in Brazil. [...] In short, we understand that the opinion of the experts we consulted with corroborates the indicators found in the literature in that they show the "exceptional" contribution of the Gymnastics Festivals to personal and professional development of those involved.

Within the scope of GfA ${ }^{a}$ that was studied and reviewed a, it was observed that researchers still fail to delve into the topic of CC in GfA and, in this context, this study aims to create/propose a procedure to examine and record CC in GfA through analytical records. Such records could be useful to teachers and gymnasts in order to enhance their individual and/ or collective characteristics as an encouragement for them to take part in domestic and international events, in addition to keeping an accurate and detailed record of their compositions (which could also serve as a historical record of the group).

At the same time, we aim at contributing to the professional training of those involved in GfA, bridging a likely gap in vocational training.

\section{Method}

The methods used in this research are bibliographical and documentary.

The bibliographical research aims to put the researcher in direct contact with all material that has been written, said or filmed on a given subject $^{23}$. This type of research includes sources such as books, articles, theses, dissertations, and monographs. For the purposes of this study we searched all the books whose titles mentioned the following terms: Gymnastics for All, General Gymnastics, and Choreographic Composition found in Brazilian book databases. The articles were obtained from scientific digital platforms as SciElo and WebScience, as well as from journals in the specific field of Gymnastics, such as Science of Gymnastics Journal, mentioning the same keywords as those found in the books. It is worth mentioning that abstracts and articles were also searched in the annals of all editions of the International Forum of General Gymnastics (2001, 2003, 2007, 2010, 2012, 2014), and those keywords were also searched in the theses and dissertations available on CAPES portal (a Brazilian national electronic library consortium for science and technology). This survey was conducted from January 2014 to March 2015.

The documentary research, on the other hand, ${ }^{24}$ : is characterized by the information found in documents that did not receive any scientific treatment, such as reports, newspaper articles, magazines, letters, films, recordings, photographs, and other communications materials.

These documents typically provide information about the topic of the research and are available on GfA-related Association sites such as the International Gymnastics Federation ${ }^{25}$, ISCA, DGI, and also from youtube.com.

\section{Some possible ways of analyzing choreographic compositions in gymnastics for all}

Even though it is known that there are some models of CC analytical records and guidelines on this subject in the field of GfA, these have not been published in the academic arena. Examples are both the model devised by the current GfA Technical Committee of the Brazilian Gymnastics Confederation (CBG) for the accreditation of Brazilian GfA groups for the World Gymnaestrada, and the guidelines posted on FIG's website about the event "Gym For Life Challenge"26.

Undoubtedly, these tools are of great importance for the area of Gymnastics since they bring relevant information about $\mathrm{CC}$ that will also be addressed in this new model proposed.

It is important to stress that, given the variety of $\mathrm{CC}$, some aspects may not be considered by these tools. There is no need for the records to be thoroughly completed and some additional aspects may even be included. What we present below is merely a supporting model, for we understand that every choreography is unique in its varied elements and, ideally, each should also have a unique analysis and record.

Although literature brings few methodological approaches used to describe CCs, ULMER ${ }^{27}$ gathers 
a few of them: phenomenological, new materialist and Deleuzian approaches. These forms escape the academic writing conventions and each one of them has its particular features; they are considered important pedagogical tools and can take various forms and justifications for their use:

It could be used as a free-writing activity to generate ideas for writing. It could also be used to explore students' knowledge, understandings, and perceptions of dance in relation to embodiment or materiality. Further, it could be modeled or used as an in-class lesson to demonstrate the performative and creative possibilities of writing.

The first part of this study has already been published $^{28}$ and proposed a system of analytical records for the General Aspects of CC in GfA. We will refer to this first part of the study in this paper and will also propose a recording system for its Specific Aspects (the ultimate goal of this study). This paper will present the complete proposal of analytical records for CC in GfA.

\section{General aspects of choreographies}

The proposal of keeping analytical records starts with Analytical Record 1 - which is a general characterization of the choreographic composition containing basic information that is typically found in registration forms or participant information forms for groups participating in gymnastics festivals.

TABLE 1 - Analytical Record 1: General characterization of the choreographic composition.

Source: Translated and adapted from SCARABELIM and $\operatorname{TolEDO}^{28}$ (p.191).

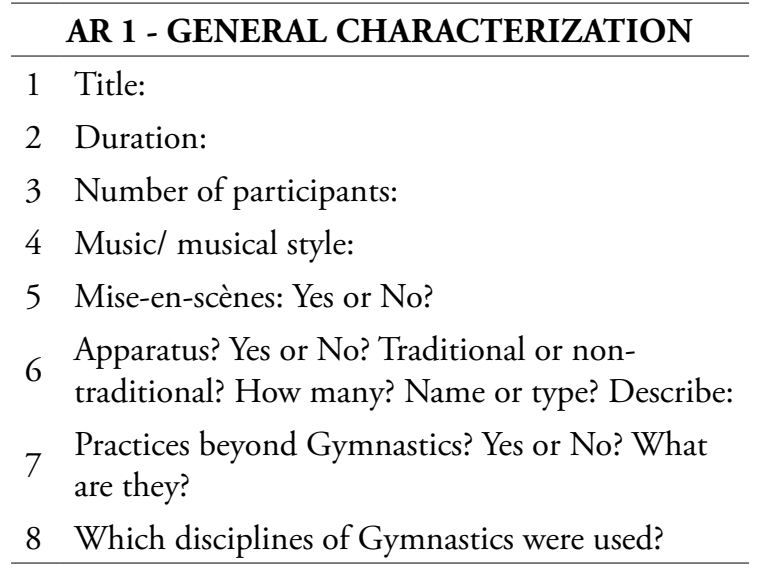

In their structure, CC is essentially composed of choreographic formations that may or may not be geometric ${ }^{15}$. All choreographic formations determine the spatial positioning of the participants at a given moment of the choreography ${ }^{29}$, and
Toledo $^{15}$ also stresses that gymnasts need to remain in the formation for a period of time, so that it can be truly regarded as a choreographic formation. Otherwise, it will be characterized as a choreographic transition, which is a form of move in which a choreographic formation shifts to another.

Thus, the next record will address which formations are part of this particular CC, including a description of what is performed in each one.

According to RochA" ${ }^{30}$, the "Graphic cells are made up of drawings of the performing space in their due proportions and with the suggested adjustments", representing what we wish to elucidate by making use of appropriate symbols.

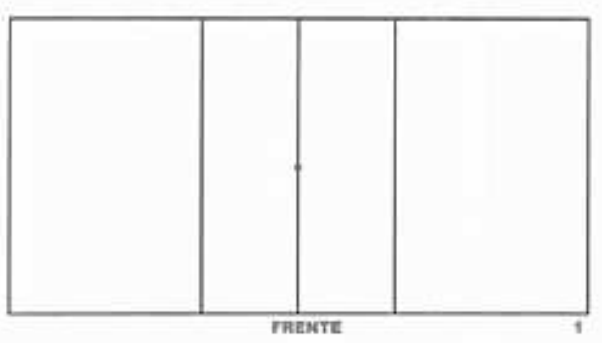

Source: $\operatorname{RocHA}^{30}$ (p.26)

FIGURE 1 - Graphic cell.

Considering that each graphic cell represents a choreographic moment, a CC should contain some or many of such cells, all of which must be properly identified. In addition, an extra space should be provided for descriptions and/or comments. The methodology developed by the author basically consists of five steps or processes:

1) Definition of the graphic cell and the standardization of the stage front and the length in meters;

2) Definition of the choreography and numbers associated with it (number of participants, number of formations, etc.);

3) Outline (sketch) of the formations, with their identification and the positioning of the elements;

4) Recording in the graphic cell by means of documentation (photos, videos, etc.) and;

5) Subsequent checks for possible corrections.

This model was used and improved by BORTOLETO and PINTO ${ }^{31}$, who propose a model with a graphical representation of the CC space, given the need to record the activities of the Unicamp Gymnastics Group (GGU).

The symbols relating to the elements that make up a particular choreographic moment may be different. 
For this study, we adopted the symbols already defined by Bortoleto and Pinto ${ }^{31}$, as follows: fast moves, slow moves, boys and girls; adding, simultaneously, other three descriptions/details: low, middle and high levels and their respective symbolism:

TABLE 2 - Symbols used for different activities in a graphic cell.

\begin{tabular}{|c|c|}
\hline Activity & Symbol \\
\hline Fast moves & $\rightarrow$ \\
\hline Slow moves & $\cdots$ \\
\hline Boys & • \\
\hline Girls & ○ \\
\hline Low level & $\nabla$ \\
\hline Middle level & $>$ \\
\hline High level & $\Delta$ \\
\hline
\end{tabular}

We believe that the identification of the levels that the gymnast uses during the choreographic composition is important because it is based on such identification that one can get a better sense of the figure formed by the gymnasts at that choreographic moment, or by the apparatus they use, as stated by SANTOS and SANTOS?:

It is important to stress that the possibilities of figures can also be executed with the use of materials, as well as with the group members, not only at the floor level, but also considering the possibility of executing "balances" such as human pyramids or by using aerial apparatus.

According to the authors Toledo and SCARABELIM $^{28}$

The symbols relating to the levels must accompany the symbol of each member/gymnast because, during the choreography, gymnasts may occupy different levels at the same time. They can also be used for representing a choreographic formation as a whole. It is suggested that the symbols of the levels should be represented on a slightly smaller scale in order to avoid possible visual pollution and to achieve a faster identification. If in a given choreographic formation the gymnast should use more than one level, both must be identified.

Therefore, Analytical Record 2 - Layout of the choreographic composition, includes the CC graphic cells, with their symbols and descriptions. Here is an example of a graphical cell:

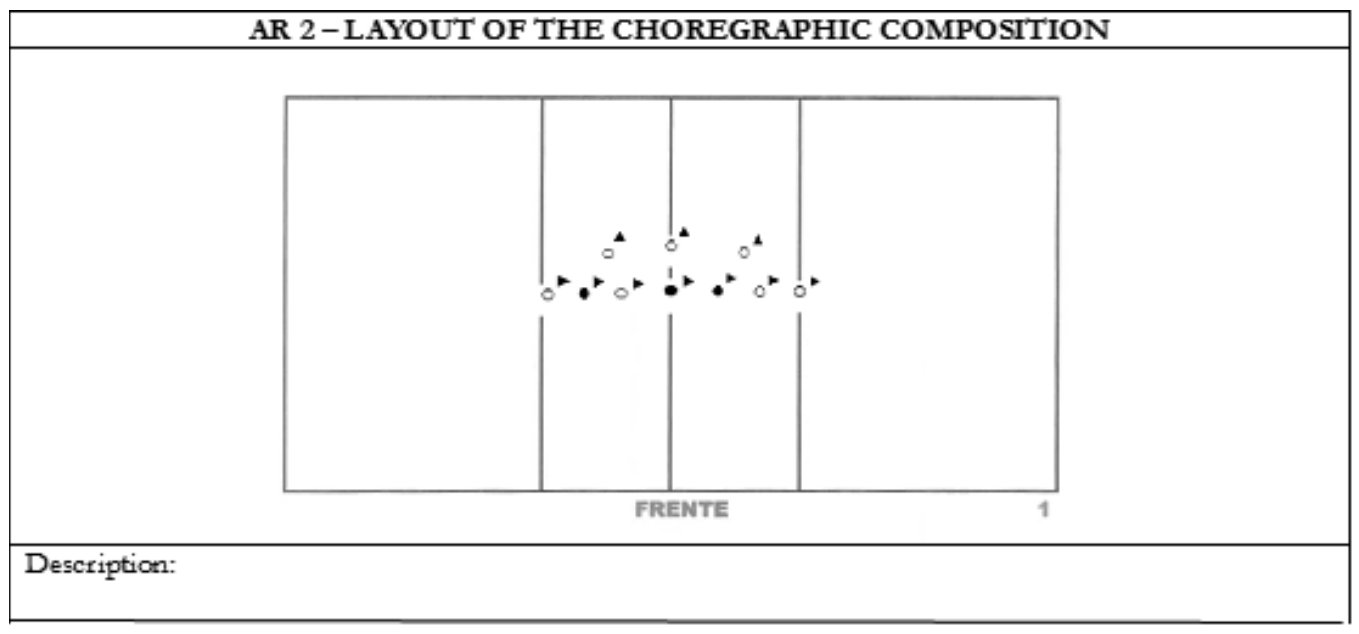

Source: Translated and adapted from: SCARABELIM and TOLEDO ${ }^{28}$ (p.190).

FIGURE 2 - Analytical Record 2: layout of the choreographic composition.

Analytical Record 3, which was created specifically for the purposes of this paper, aims to conduct a typological and quantitative analysis of the choreographic formations of a CC based on the information provided in Record 2. This enables the assessment of what and how many shapes are formed in the performing space. 
TABLE 3 - Analytical Record 3: quantitative and type analysis of choreographic formations.

\begin{tabular}{l}
\hline \multicolumn{1}{c}{ AR 3 - QUANTITATIVE AND TYPE ANALYSIS OF CHOREOGRAPHIC FORMATIONS } \\
\hline \multicolumn{1}{c}{ Choreographic formations } \\
\hline Circles \\
Semicircles \\
Straight lines (lines/columns) \\
Squares \\
Triangles \\
Spirals \\
Diagonals \\
X shapes \\
Oval shapes \\
Fish school shapes \\
V shapes \\
Others \\
\hline Total
\end{tabular}

There is no minimum or maximum number of formations for each CC, because this amount is associated with other factors such as the purpose of the composition, its theme, its duration, the group profile, among others. However, it is interesting to rely on such records to analyze which formations have previously been used and which may be used in the future. It is then possible to check if there are repeated formations (whose variation is only in their dimensions) or very similar set of formations (as circles/semicircles, or diagonals/V-shaped or $\mathrm{X}$-shaped). In both cases, CC may become repetitive, monotonous and demotivating to those who are watching it and/or to those who are practicing it.

The Scarabelim and Toledo ${ }^{28}$ also point out that:

The said eight items are directly linked to a conception of GfA, where the choreographic composition is taken as a unit, that is, a practice that highlights the experiences of its practitioners and the unique characteristics of this gymnastics practice, namely, the use of materials, different expressions of body language and the arts, gymnastics practices, to name a few 9; 10; 14. We stress that these items mentioned in the analytical records are not mandatory, and there is no impediment for CC to use some of the items mentioned while leaving others out because, otherwise, we would be moving away from an inclusive, free and creative proposal that should value, above all, the unique features of each individual group. In this context, the questions asked in these eight items intend to elicit the details of the general choreographic aspects so as to better describe CC.

There is also a third analytical record, which refers to the qualitative analysis of the general choreographic components that are common to all routines.

TABLE 4 - Analytical Record 4: qualitative analysis of the general choreographic components.

Source: Translated
and adapted from:
SCARABELIM and TOLEDO ${ }^{28}$
(p.192).
*Opinion: Regular,
Satisfactory, Good, Very Good, Excellent.

\section{AR 4 - QUALITATIVE ANALYSIS OF THE GENERAL CHOREOGRAPHIC COMPONENTS}

\begin{tabular}{llcc}
\hline & & Description & Opinion* \\
\hline 1 & Music-movement relationship & \\
2 & Clean movements & \\
3 & Execution of acrobatic elements & \\
4 & Transitions \\
5 & Space Use & \\
\hline
\end{tabular}


The Scarabelim and Toledo ${ }^{28}$ point out that the reasons that guided the creation of this record and the choice of each single item used are based on different studies, fundamentally conducted by SAntos and SAntos?. These items, in summary, refers to:

1) Music-movement relationship: check whether or not the movements are performed in harmony with the music based on an analysis of tempo, melody, accents, pulse, beat, musical alternations, among others. The rhythm of the music should be aligned with the rhythm of the movements of the gymnasts in the choreography, where both should nearly make up a single choreographic element ${ }^{20}$. According to the authors, in a GfA choreography, this rhythmic harmony is essential.

2) Clean movements: consider if the movements are carried out collectively (should that be the goal), if they are clear to the spectator (individually or collectively), if the movements do not pose risks to the gymnasts should failures occur in the execution (which might reveal gaps in the learning process), among other aspects. [...]

3) Execution of acrobatic elements: consider whether the acrobatic elements are being carried out satisfactorily or if there is the need for/possibility of improvement. Description of the acrobatic elements (number of people participating, where they occur, etc.). Acrobatic elements are very interesting to be used in a choreographic composition, as they bring a challenge and risk profile, creating positive feelings in the audience as well as in those who practice these elements.

4) Transitions: characterize how transitions are performed between one formation and another, identifying the quantity, whether they are carried out using gymnastic elements or dance moves, if they are executed as one single group or in small groups, etc. There are other types of transitions in a GfA choreography, such as the transition from one movement to the other, from one song to the other, from one rhythm to the other ${ }^{20}$. However, for this analytical record, we suggest that transitions between choreographic formations are described and analyzed. Priority should be given to the homogeneity and unity of the performance by means of transitions that flow harmoniously ${ }^{20}$. 5) Space Use: Description of how the space is used by gymnasts through formations and transitions and if they concentrate more in a particular place or if the entire space is used, etc.

\section{Specific aspects of the choreographic composition}

Once the analytical records that refer to the general aspects of the CC are completed, other records on the specific aspects of CC can be started. Thus, Analytical Record 5 relates to the typological and quantitative analysis of the basic elements of gymnastics that are present in CC:

TABLE 5 - Analytical Record 5: typological and quantitative analysis of the basic elements of gymnastics.

\begin{tabular}{|c|c|c|c|c|c|c|c|c|}
\hline \multicolumn{9}{|c|}{ AR 5 - TYPOLOGICAL AND QUANTITATIVE ANALYSIS OF THE BASIC ELEMENTS OF GYMNASTICS } \\
\hline $\begin{array}{l}\text { Elements/ } \\
\text { Types or names }\end{array}$ & Swing & Circumduction & Balances & $\begin{array}{c}\text { Rotations/ } \\
\text { Pivots }\end{array}$ & "Waves" & $\begin{array}{c}\text { Individual } \\
\text { Acrobatic } \\
\text { Elements }\end{array}$ & Small Jumps & $\begin{array}{c}\text { Jumps/ } \\
\text { Leaps }\end{array}$ \\
\hline \multicolumn{9}{|l|}{ Type } \\
\hline \multicolumn{9}{|l|}{ Type } \\
\hline \multicolumn{9}{|l|}{ Type } \\
\hline \multicolumn{9}{|l|}{ Type } \\
\hline \multicolumn{9}{|l|}{ Total Number } \\
\hline $\begin{array}{l}\text { Suggestions/ } \\
\text { or Analysis }\end{array}$ & & & & & & & & \\
\hline
\end{tabular}

The proposal of Record 5 is based on Souza et al. ${ }^{32}$, and aims to determine what are the body or gymnastics elements present in CC and its typologies. As a result, one can clearly see the elements used in
CC, and those that are underutilized or unused. In addition, it provides accurate data about the typology of the elements used, with their specific nomenclatures, thus allowing the identification of repetitions, 
variations and/or absence of certain elements. It is worth mentioning that the completion of this record contributes to the technical training of teachers and participants, since it requires the knowledge of a language typically used in the field of gymnastics. It also demands a creative process when defining any new nomenclature for elements created by those involved.
Another specific component of a GfA choreography, which is directly related to gymnastic elements, are the inverted positions (static or dynamic), also referred to as acrobatic elements. Thus, Analytical Record 6 aims to conduct a typological and quantitative analysis of the acrobatic elements:

TABLE 6 - Analytical Record 6: typological and quantitative analysis of the acrobatic group elements.

\section{AR 6 - TYPOLOGICAL AND QUANTITATIVE ANALYSIS OF THE ACROBATIC GROUP ELEMENTS}

\begin{tabular}{lcc}
\hline Acrobatic group elements & Types/Names & Total \\
\hline Balance exercises & & \\
Dynamic exercises & \\
Combined exercises & \\
\hline
\end{tabular}

The determination of these three types of acrobatic group elements was based on the studies conducted by Perez-Gallardo and Azevedo ${ }^{33}$, Merida $^{34-35}$ and FIG ${ }^{36}$. Therefore PEREZ-Gallardo and AzEveDo ${ }^{33}$ :

The balance exercises (or static positions) are exercises in which the partners form and maintain a pose for at least three seconds. This kind of movement is also characterized by transitions, which are movements performed by the base, by the top or both, in order to form a pose in which the partners do not shift their support during a transition.

In the dynamic exercises, the essential characteristic is the existence of a phase that includes the flight of the top. During this phase, the top performs movements such as somersaults or twists.

Since GfA is an essentially collective practice, there are many relationships between the ways acrobatics are performed and in Acrobatic Gymnastics (AcroG). In both, $\mathrm{CC}$ is present and one can see moments when acrobatics are performed in groups or individually, on the floor or in the air. Acrobatic elements are typical of gymnastics practices in general and are present in several of them, both in competitive or demonstrative modalities. Acrobatic elements are appealing to CC because regardless of whether they are mandatory or not, they give a sense of challenge and risk, both to those who practice it, and to the audience. Some of these elements have a higher level of difficulty and, when well executed in CC (individually or in groups), cause a very positive impact on the audience.

Both gymnastic and acrobatic elements are widely used in CC of GfA, since these are also influenced by other types of gymnastics, such as artistic (where acrobatics prevail) or rhythmic (where gymnastic elements prevail). It is suggested that these elements should be both evenly and harmonically distributed, in harmony with the proposed theme of the CC of GfA.

In general, as previously pointed out by some authors, CCs have an inspiring theme that may be triggered by a song, a cultural feature (of the group, region, and country), an apparatus, or any other source. Moreover, in case of a thematic choreographic composition, it would be interesting to conduct an analysis only on the coherence with the theme, according to the proposal of Analytical Record 7:

TABLE 7 - Analytical Record 7: coherence theme analysis.

\section{AR 7 - COHERENCE THEME ANALYSIS}

\begin{tabular}{lllll}
\hline Components / Analysis & Theme of the CC & Costumes & Music & Apparatus \\
\hline Description & & & \\
Analysis & & & \\
Suggestion & & & \\
\hline
\end{tabular}


The following information could be present in each of these components:

- Theme of the choreography: what it is, how and when it was chosen, what are its main characteristics and the reasons for selecting it;

- Costumes: how many outfits it uses, name (for those which are folk-based or typical of a region), description (design, colors), how and why they were chosen (related to the theme);

- Music: how, when and why it was chosen; style or musical rhythm; technical data (name, author, group/band, album, length etc.), relationship with the theme, and forms of music mixing (if any);

- Apparatus: how, when and why it was chosen, name, color, size (small, medium or large), shape, quantity, relation to the theme.

The teacher/coach or even the gymnasts can fill out this form and analyze whether there is coherence between these four choreographic aspects, also marking suggestions for future changes or minor adjustments. It is not uncommon to see CC at festivals that show a mismatch between those aspects. Besides, as we understand it, this alignment is precisely one of the principles that draws GfA close to its artistic and performing roles.

For GALLARDO ${ }^{29}$, there are subjective aspects in a CC that are related to the human development of its practitioners, such as cooperation, organization, responsibility, honor, respect, solidarity, creativity, among other. Given this subjectivity, CCs are difficult to be measured in a more objective analysis. Nevertheless, the authors consider to be possible to narrate (or describe) these subjective aspects of CCs using a system of analytical records developed for this purpose.

As already mentioned by some authors ${ }^{1,12,15}$, GfA stands out as a unique practice in its choreography development process, since it values inclusion, socialization, and human development, among other aspects. Taking all this into consideration, we realized that one of the records should focus exclusively on this aspect, and that perception gave rise to ANALYTICAL RECORD 8.

TABLE 8 - Analytical Record 8: the choreographic composition process.

\section{AR 8 - THE CHOREGOGRAPHIC COMPOSITION PROCESS}

Description:

This record can be used for a brief description of the "step-by-step" development of the choreography, with specifications as to the order and the way CC gradually materializes. This description can be provided by means of a script, as follows: What did we do first? How did we choose the theme, the music, and the apparatus? Then, what did we do? Did we define the formations, divided the group into two for an early creative process using the apparatus? And so on. Alternatively, this analytical record could be developed in a narrative format, as if we were telling the story of the creative process of the composition. In both cases, in order to compile a collection of chronological records, the authors suggest that, during this choreographic development process, records should be made (by means of photos, videos, and testimonials) so that they would become part of this record at the end of the process.

\section{Discussion}

The main objective of this study was to propose a choreographic analytical tool to be used in GfA, consisting of a set of eight analytical records (AR), which address general and specific aspects of CC, duly supported by the theoretical references in the area. This tool enables the assessment of the following aspects:

- AR1 - General characterization of the choreographic composition;

- AR2 - Layout of the choreographic composition;
- AR3 - Quantitative and type analysis of choreographic formations;

- AR4 - Qualitative analysis of the general choreographic components;

- AR5 - Typological and quantitative analysis of the basic elements of gymnastics;

- AR6 - Typological and quantitative analysis of the acrobatic group elements;

- AR7 - Coherence theme analysis;

- AR8 - The choreographic composition process. 
Therefore, this study contributes to the production of new scientific knowledge in the field of GfA, as well as to the activities of teachers and participants of GfA, enabling them to:

- organize, in a single document, detailed information about the choreographic composition created;

- have a tool for the analysis of each composition; - enhance or propose changes to the choreography, from the identification of items or components that were not covered, but that could be included (should the group be willing to), by assessing the information available on the records;
- use these records for future objectives or challenges to the group (replacement of members; implement partial changes to meet the rules of a festival);

- become a historical choreographic collection of the group;

- obtain organized and detailed information about CC for future scientific work.

Far from being an "evaluative" and "standardizing" understanding of the choreographic compositions of the GfA, the purpose of this study was rather to praise the qualities of GfA, according to RussEL ${ }^{37}$. We agree with Toledo and SCHiavon ${ }^{38}$ that "its identity lies precisely in its diversity"!

\section{Notes}

a. These references and choreographies of national and international festivals were discussed on the theme "Choreographic Compositions in GfA." The reference used in the research is described in Method.

The author Maria Leticia Abud Scarabelim is a researcher at LAPEGI - Laboratory of Gymnastics Researches and Experiences, Faculty of Applied Sciences, University of Campinas.

The author Eliana de Toledo is coordinator of LAPEGI - Laboratory of Gymnastics Researches and Experiences, and professor of the Sports Science Course, Faculty of Applied Sciences, University of Campinas.

\section{Resumo}

Proposta de fichas analíticas de composições coreográficas na ginástica para todos

A Ginástica para Todos (GPT) é uma prática encontrada no amplo universo da ginástica, e a sua maior forma de expressão se dá por meio de composições coreográficas (CC), por motivos históricos, pedagógicos, entre outros. E os festivais de ginástica vêm se mostrando, em nivel internacional, como um fórum privilegiado de mostra das $\mathrm{CC}$, ocorrendo em diferentes contextos de intervenção social, como escolas, clubes, associações, ONGs e universidades. Nesse contexto, nosso objetivo é fornecer um instrumento para registrar e analisar composições coreográficas de GPT, por meio de fichas analíticas. A partir de uma pesquisa bibliográfica e documental, propõe-se um conjunto de oito fichas analíticas, que abordam aspectos gerais e específicos das CC na GPT. Conclui-se que o instrumento proposto possui uma estrutura didática e bem detalhada, alicerçada nas prerrogativas teóricas da área, o que viabiliza seu uso por diferentes perfis de profissionais e praticantes, podendo ser de grande valia para todos os envolvidos nos processos de CC na GPT, como uma ferramenta de registro (inclusive histórico), catalizadora de processos de reflexão e mudanças (caso sejam necessárias).

Palavras-Chave: Ginástica para todos; Composição coreográfica; Ciências do esporte; Coreografia. 


\section{References}

1. Souza EPM. Ginástica geral: uma área do conhecimento da educação física [tese]. Campinas (SP): Universidade Estadual de Campinas, Faculdade de Educação Física; 1997.

2. Fedération Internationale de Gymnastique. Gymnastics for all regulation manual, 2009. Lausanne: FIG; 2009. Available from: www.fig-gymnastics.com.

3. Perez-Gallardo JS, Souza EPM. La experiência del grupo ginástico Unicamp en Dinamarca. III Congresso Latino Americano - ICHPER; 1995; Foz do Iguaçu, BR. Foz do Iguaçu: ICHPER; 1995. p.292-8.

4. Scarabelim MLA. Fichas analíticas de composiçóes coreográficas na ginástica para todos: primeiros ensaios [monografia]. Campinas (SP): Universidade Estadual de Campinas, Faculdade de Ciências Aplicadas; 2014.

5. Dantas M. O enigma do movimento. Porto Alegre: UFRGS; 1999.

6. Silva ER. O que essa obra de arte me diz? Salvador: Universidade Federal da Bahia; 2008. Disponível em: www.portalabrace.org.

7. Laban R. Choreutics: annotated by Lisa Ullmann. London: MacDonald and Evans; 1963

8. Criollo YSN. Programa de entrenamiento para la escuela de gimnasia artística feminina de la Federación Deportiva del Azuay de 5 a 6 años [tesis]. Cuenca (Equador): Universidad Politecnica Salesiana; 2013.

9. Santos JCE, Santos NGM. Ginástica para todos: elaboração de coreografias e organização de festivais. Jundiaí: Fontoura; 2009.

10. Gerlin I. The elements of choreography. Austin: Ballet Austin Academy. Available from: http://www.balletaustin.org/ education/documents/ElementsofChoregraphyHandout.pdf.

11. Paoliello E, Toledo E, Ayoub E, Bortoleto,MAC, Graner L. Grupo Ginástico Unicamp 25 anos. Campinas: UNICAMP; 2014.

12. Ayoub E. Ginástica geral e educação física escolar. 3rd ed. Campinas: UNICAMP; 2011.

13. Toledo E, Tsukamoto MHC, Gouveira CR. Fundamentos da ginástica geral. In: Nunomura M, Tsukamoto MHC, organizadoras. Fundamentos das ginásticas. Jundiaí: Fontoura; 2009. p.23-50.

14. Pollatou E, Hatzitaki V, Karadimou K. Rhythm or music? Contrasting two types of auditory stimuli in the performance of a dancing routine. Percept Mot Skills. 2003;97:99-106.

15. Toledo E. Nomination of the choreographic formations: feasibility and meanings. III Fórum Internacional de Ginástica Geral; 2005; Campinas, BR. Campinas: FEF/UNICAMP; 2005. p.99-102.

16. Silva Y. Ginástica geral: um processo de construção coreográfica com crianças. In: Toledo E, Silva PC, organizadores. Democratizando o ensino da ginástica: estudos e exemplos de sua implantação em diferentes contextos sociais. Várzea Paulista: Fontoura; 2013. p.97-120.

17. Banjak SJ. Sokol: gymnastic manual. East Orange: The Slovak Gymnastic Union Sokol; 1993.

18. Kubin Z. XIV Vsesokolský SLET. Praha: Plot; 2006.

19. Neumann H. Deutsche Turnfeste - Spiegelbild der deutschen turnbewegung. Wiesbaden: Limpert; 1987.

20. Wichmann A. The historical roots of the gymnaestrada: national gymnastics festivals in nineteenth-century Europe. In: Merkel U, organizer. Power, politics and internation events: socio-cultural analyses of festivals and spectacles. New York: Routledge; 2013.

21. Mechbach J, Waneberg PL. The world gymnaestrada: a non-competitive event. The concept “Gymnastics for All” from the perspective of ling gymnastics. Scand Sport Stud Forum. 2011;2:99-118.

22. Patrício TL, Bortoleto MAC. Festivais ginásticos: princípios formativos na visão de especialistas. Conexôes. 2015;13:98-114.

23. Lakatos EM, Marconi MA. Fundamentos de metodologia científica. 5a ed. São Paulo: Atlas; 2003.

24. Oliveira MM. Como fazer pesquisa qualitativa. Petrópolis: Vozes; 2008.

25. Fedération Internationale de Gymnastique. About gymnastics for all. Lausanne: FIG; 2015. Available from: http:// www.fig-gymnastics.com.

26. Fedération Internationale de Gymnastique. Gym for life challenge. Lausanne: FIG; 2015. Available from: http:// www.gymforlife2017.com/.

27. Ulmer JB. Embodied writing: choreographic composition as methodology. Res Dance Educ. 2015;16:33-50.

28. Scarabelim MLA,Toledo E. Proposta de criação de uma ficha analítica de composiçôes coreográficas na ginástica para todos: primeiros ensaios. Conexôes. 2015;13:181-96.

29. Gallardo JSP. Critérios de avaliação de composições coreográficas desenvolvidas em grupos de ginástica geral da Faculdade de Educação Física da Unicamp. I Congresso Latino-Americano de Educação Motora, II Congresso Brasileiro de Educação Motora; 1998; Campinas, BR. Campinas: UNICAMP; 1998. v.1, p.608. 
30. Rocha B. Diagramação e registro de coreografias do Grupo Ginástico Unicamp. Rev Corpoconsciência. 2004;13:77-92.

31. Bortoleto MAC, Pinto L. The graphic representation of a general gymnastics choreography: the case of Urban Moviments of Gymnastics Group of Unicamp (GGU). IV Fórum Internacional de Ginástica Geral; 2007; Campinas, BR. Campinas: FEF/UNICAMP; 2007. p.253-8.

32. Souza EPM, Toledo E, Palermo CT. Manual e vídeo de elementos básicos da ginástica rítmica desportiva: com e sem aparelhos. Campinas: Centro de Comunicação da UNICAMP; 1997. Elementos corporais.

33. Perez-Gallardo JS, Azevedo LHR. Fundamentos básicos da ginástica acrobática competitiva. Campinas: Autores Associados; 2007. Os exercícios acrobáticos.

34. Merida FV. Fundamentos da ginástica acrobática. In: Nunomura M, Tsukamoto MH, organizadoras. Fundamentos das Ginásticas. Jundiaí: Fontoura; 2009. p.173-200.

35. Merida FV. Ensinando a ginástica acrobática. In: Nista-Piccolo VL, Toledo E, organizadoras. Abordagens pedagógicas do esporte. Campinas: Papirus; 2014. p.123-41.

36. Fedération Internationale de Gymnastique. Code of Points acrobatic gymnastics: 2013. Lausanne: FIG; 2013. Availabre from: www.fig-gymnastics.com.

37. Russel K. Gymnastics challenges: a view form 50 years of coaching and teaching. In: Schiavon LM, Heinen T, Bortoleto MAC, Nunomura M, Toledo E. High performance gymnastics. Hildesheim: Arete-Verlag; 2014. p.1-17.

38. Toledo E, Schiavon LM. Ginástica geral: diversidade e identidade. In: Paoliello E, organizadora. Ginástica geral: experiências e reflexôes. São Paulo: Phorte; 2008. p.216-39.

\begin{tabular}{r|c} 
ENDEREÇo & \\
Maria Letícia Abud Scarabelim & Recebido para publicação: 04/11/2015 \\
Faculdade de Ciências Aplicadas & Aceito: 15/12/2015 \\
Universidade Estadual de Campinas & \\
R. Pedro Zaccaria, 1300 - Campus Limeira & \\
13484-350 - Limeira - SP - BRASIL & \\
e-mail: marialeticiascarabelim@gmail.com &
\end{tabular}

